\title{
Subglottic Cancer Clinical Distant Metastasis TNM Finding v7
}

National Cancer Institute

\section{Source}

National Cancer Institute. Subglottic Cancer Clinical Distant Metastasis TNM Finding v7. NCI Thesaurus. Code C89088.

A clinical finding about one or more characteristics of subg lottic cancer, following the rules of the TNM AJCC V7 classification system as they pertain to distant metastases. 